This spring, 56 promising minority students interested in pursuing graduate studies in political science were identified by political science departments at Amherst College, Butler University, University of California, Santa Cruz, Chicago State University, Goucher College, Harvard University, Marquette University, University of Michigan, Monmouth University, University of New Mexico, University of North Carolina, Ohio State University, University of Oklahoma, University of Rhode Island, Santa Clara University, University of South Carolina, Aiken, University of Southern California, Virginia State University, Washington University, and Xavier University. APSA would like to express its appreciation to these departments for their support and participation.

The Minority Identification project is a collaboration of undergraduate and graduate political science programs to attract talented minority undergraduate students to graduate study in the field and, ultimately, to increase diversity in the political science profession.

Faculty in university and college undergraduate programs talk with minority students about professional careers in political science and send the names of promising minority candidates for graduate study to the APSA. Participating graduate institutions actively recruit students identified by the Project, and make special

1998-99 APSA Minority Fellows Choose Grad Schools

All four 1998-99 Minority Fellows will be attending graduate school this fall. Latina Fellow Luz Iniz Gomez will enter the Ph.D. program in political science at Columbia. African-American Fellows Kimberly Clark and Temita Davis will attend the University of North Carolina and Clark University, respectively. Brandy Faulkner, an unfunded Fellow, has accepted admission to the University of North Carolina, Greensboro. efforts to provide financial aid to those admitted to their programs.

Currently, the Project circulates its list to 41 core schools and to several non-core schools. For more information about the Project, please contact minority_id@apsanet.org.

\section{Forty-Sixth Class of Congressional Fellows Named}

Continuing a five-decade tradition, APSA has named its 1998-99 class of Congressional Fellows. Chosen from a large and highly qualified group of political scientists, journalists, health professionals, and government employees, Fellows will spend a year in Washington learning how the legislative branch of the federal government works by joining the staffs of members of Congress and attending lectures and seminars.

The 1998-99 Congressional Fellowship Program class includes:

\section{Political Science Fellows}

David Auerswald, assistant professor, George Washington University

Thomas Brunell, visiting professor, University of California, Irvine

Colton Campbell, assistant professor, Florida International University

Lisa García Bedolla, Ph.D., Yale University

Eric Heberlig, Ph.D., Ohio State University

Benjamin Highton, Ph.D., University of California, Berkeley

David Leal, assistant professor, State University of New York, Buffalo (1998-99 Steiger Fellow)

\section{Journalism Fellows}

Natalia Feduschak, contributing editor, The Ukrainian Quarterly

Darcia Harris, staff writer, The $\mathrm{Wa}$ tertown Daily Times (1998-99 Congressional Quarterly Fellow)

APSA-MCI Communications Fellows

Daniel Lipinski, Ph.D., Duke University

Andrew Souvall, producer, KUTV, Salt Lake City, Utah
Carl Albert Fellows

Lesli McCollum, Ph.D., University of Oklahoma

German Fellows

Katherine Käufer, computer software translator, Graphitti Software, Cologne, Germany

Michael Kühlen, freelance journalist, Münster, Germany

\section{Federal Fellows}

Lora Becker, director of military intelligence staff, Defense Intelligence Agency

Donna Counterman, chief, EMS Requirements Staff, and EMS business manager, Central Intelligence Agency

Blane Dessy, executive director, $\mathrm{Na}$ tional Library of Education, U.S. Department of Education

Deirdre Foley, fair lending specialist, Federal Deposit Insurance Corporation

Christine Jackson, education program specialist, U.S. Department of Education

Patricia Jones, chief, Infrastructure Planning and Strategy, and senior computer scientist, National Security Agency

Arthur Menna, senior electronic engineer, National Security Agency

Carol Rest-Mincberg, senior management consultant, Department of Health and Human Services

Stacey Rosenberg, nuclear engineer, Nuclear Regulatory Commission

Foreign Affairs Fellows

William Adkins, team chief, Advanced Concepts Group, National Reconnaissance Office

Anne Alexander, Defense Intelligence Agency

Christopher Datta, country affairs officer (Israel, Jordan, Lebanon, Syria, West Bank), U.S. Information Agency

Delia Donatelli, deputy division chief, Satellite Systems Division, Department of the Air Force 
John McNamara, senior watch officer, Operations Center, Department of State

Lt. Col. Terry Robling, operations action officer, U.S. Marine Corps

Susan Rzemien, international economist, Office of Foreign Exchange Operations, Department of Treasury

David Salazar, foreign affairs economic analyst, Bureau of Intelligence and Research, Department of State

Joseph Stager, chief, Administrative Branch, Office of Finance and Logistics, Central Intelligence Agency

Daniel Stewart, vehicle manager, Directorate of Science and Technology, National Reconnaissance Office

Karen Walter, chief, International Branch, Federal Deposit Insurance Corporation

\section{Robert Wood Johnson Health Policy Fellows}

Robert E. Barsley, professor, oral diagnosis, medicine, and radiology, and director, department of dental health resources, Louisiana State University School of Dentistry

David E. Fleischer, professor of medicine, and chief, endoscopy unit, Georgetown University Medical Center

Marc Hahn, director, Pain Medicine and Palliative Care Center, and associate professor of anesthesia, Pennsylvania State University, Geisinger Health System

Lawrence D. Kerr, assistant professor, microbiology and immunology and cell biology, Vanderbilt University

Mary Beth Mazanec, associate professor of medicine and pathology, Case Western Reserve University

David A. Pollack, medical director, Mental Health Services, West, Inc., Portland, OR

Thomas B. Valuck, associate hospital administrator and director of medical staff affairs, University of Kansas Medical Center.

Since its inception in 1953, the Congressional Fellowship Program has given participants the opportunity to obtain "hands-on" experience of the legislative process in Congress and then take that knowledge back to their respective agencies and institutions to foster better understanding of our national legislature.

The 1998-99 Selection Committee for the political scientists and journalists included Burdett Loomis, professor of political science at the University of Kansas; Chris Deering, professor of political science at George Washington University; Ron Elving, an editor for Congressional Quarterly; Cheryl Miller, professor of political science at the University of Maryland; Barbara Vobejda, a reporter for The Washington Post; and Rebekah Young, a producer for ABC News.

German Fellows are selected and sponsored by the German Marshall Fund of the United States in conjunction with the Johann Wolfgang Goethe-Universität, Frankfurt am Main, and the Zentrum für Nordamerika-Forschung (ZENAF).

The Congressional Fellowship Program is endowed by MCI Communications Corporation. Additional
Fellowships are supported by Congressional Quarterly Incorporated.

For more information on CFP, and to obtain application materials, please visit the Congressional Fellowship Program web site (www. apsanet.org/CFP/cfpad.html), or contact the CFP staff at (202) 483-2512.

\section{Association Participates in Coalition for National Science Funding Exhibit}

Michael Ward, a professor at the University of Washington, and Kristian Gleditsch, a doctoral student at the University of Colorado, represented APSA at the fourth annual Coalition for National Science Fund. ing Exhibit, held May 20, 1998, in Washington, DC. The CNSF exhibit is designed to showcase the crucial role the National Science Foundation plays in meeting the nation's research and education needs. All members of Congress, and appropriate staff members, were invited to meet the exhibitors and view their work.

Ward and Gleditsch's presentation, "The Political Geography of

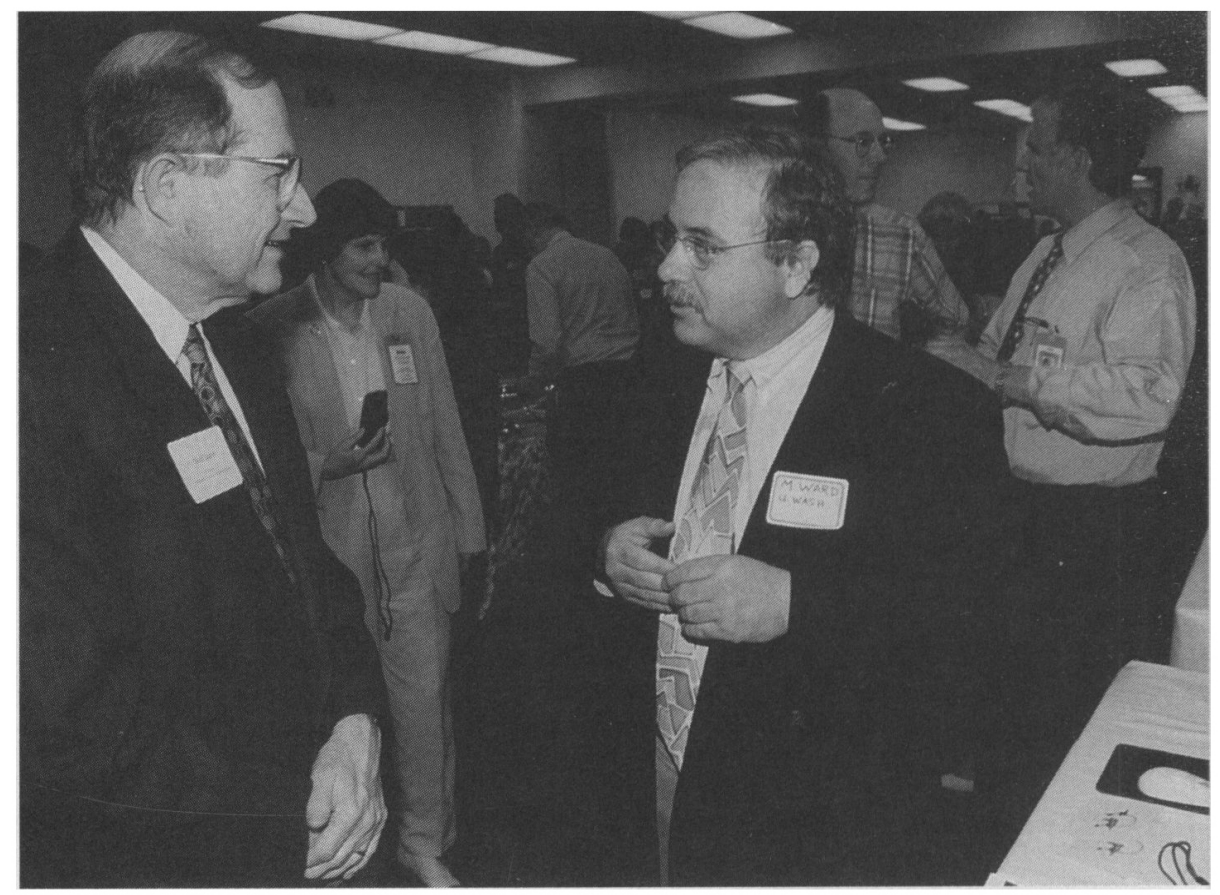

NSF Director Neal Lane (L) and Michael Ward, University of Washington, discuss Ward's exhibit, "The Political Geography of Democracy" at the Coalition for National Science Funding Exhibit and Reception on Capitol Hill. Ward's exhibit was also visited by APSA Executive Director Cathy Rudder, and NSF Political Science Program Directors Rick Wilson and Frank Scioli. 